\title{
Assessment of losses due to pulse beetle in chickpea under stored conditions in Southern Haryana
}

\section{K Rolania, SS Yadav, B Singh, JL Yadav, N Kumar \& S Pilania}

Journal of Agriculture and Ecology

Volume-12 (December, 2021) ISSN: 2456-9410

\section{Journal of}

\section{Agriculture and}

ISSN: 2456-9410

Volume: 12

Journal of Agriculture and Ecology (2021) 12: 98-105 http://doi.org/10.53911/JAE.2021.12210 


\title{
Assessment of losses due to pulse beetle in chickpea under stored conditions in Southern Haryana
}

\author{
K Rolania $\not$, SS Yadav, B Singh, JL Yadav, N Kumar \& S Pilania \\ Department of Entomology, CCS Haryana Agricultural University, Hisar, Haryana \\ \. Corresponding author: K Rolania, Email: krish81rolania@rediffmail.com
}

\section{Article Info}

Article history

Received: 30 November 2021 Accepted: 28 December 2021

Available online: 31 December 2021

\section{Key Words:}

Chickpea, storage

bruchid, losses, metal bins, earthen pots.

\begin{abstract}
The present study was carried out with the objective of assessing the losses caused by pulse beetle (Callosobruchus spp.) during storage of chickpea grains in various storage structures. It was found that, still farmers are using traditional storage structures (earthen pots, earthen pots + sand, jute bags). Chickpea grain samples (500g each) were collected during August, September and October from different storage structures (metal bins, plastic bags, gunny bags, earthen pots and earthen pots + sand) in 15 villages of Rewari, Hisar and Mahendergarh district in the year 2017 and 2018. The results of analysed samples revealed that the highest infestation was observed in Rewari followed by Hisar and Mahendergarh district. It was found that maximum number of farmers were using metal bins (51.45, $40.11 \%)$ followed by gunny bugs $(31.79,31.64 \%)$, plastic bags $(16.76$, $15.82 \%)$, Earthen pots $(6.51,7.91 \%)$ and Earthen pots + sand $(2.35,4.52 \%)$ to store the chickpea grains in 2017 and 2018, respectively. Out of total samples infested with bruchid, $70.91 \& 53.63$ per cent gunny bag samples were found infested followed by plastic bags (48.28 \& 20.29\%), metal bins $(11.24 \& 15.94 \%)$ and earthen pots $(9.80 \& 10.14 \%)$ in both the years. There was no infestation of pulse beetle observed in those samples which were stored in earthen pots along with sand. Higher moisture percentage in the grain and infestation of pulse beetle was observed in the month of September followed by October in comparison to August month. Among the storage structures in frequent use, metal bins were found to have less qualitative and quantitative losses of seed/grains.
\end{abstract}

Copyright @2021 Rolania et al., This is an open access article published under the terms of the Creative Commons Attribution License, which permits unrestricted use, distribution, and reproduction in any medium, provided the original work is properly cited.

Preferred citation: Rolania K, Yadav SS, Singh B, Yadav JL, Kumar N \& Pilania S. 2021. Assessment of losses due to pulse beetle in chickpea under stored conditions in Southern Haryana. Journal of Agriculture and Ecology, 12: 98-105; http://doi.org/10.53911/JAE.2021.12210.

\section{Introduction}

Pulses (legumes) are the second most significant group of crops for human and animal use globally (Sujeetha et al. 2020). They are high in protein (20-40\%) and carbohydrates $(50-60 \%)$, along with thiamin, niacin, calcium, and iron (Sharma et al. 2016).
Globally, 840 million people (Anonymous 2016) are malnourished, owing to insufficient protein, vitamin, and mineral consumption in their diets. Pulses, in this sense, serve a critical role in ensuring global food and nutritional security in the future (Aslam 2004). They constitute the main source of plant protein in 
developing countries like India, where per capita availability of pulses is 39.9 g/day (Chaturvedi \& Ali 2000) very low as against FAO/WHO's recommendation of 80 g/capita/day. Pulses also keep the soil alive and productive by fixing atmospheric nitrogen into soil without any extra cost (Sharma et al. 2013). In 2017-18, India produced around 23.95 million tonnes of pulses (Anonymous 2016). Chickpea is the most important pulse crop of India and occupies 8.17 million hectares with production of 7.48 million tones, accounting for 35.09 per cent and 51.02 per cent of total area and production, respectively. In Haryana total production of chickpea during 2009- 2010 was 0.06 million tones covering in about 0.08 million hectares (Anonymous 2011).

Bruchids are regarded to be one of the most damaging storage pests. More than 100 species of bruchids exist, divided into 56 genera and five subfamilies (Southgate, 1979). There are 117 species in India, classified into 11 genera (Arora 1977). A variety of commercially significant species of the genus Callosobruchus attack stored pulses all over the world. The damage and loss of seed viability caused by pulse beetle infestation is one of the key restrictions in chick pea storage. Only grubs inflict the damage because it's an interior feeder (Anonymous 2019). Seed weight and protein content declines in pulses of roughly 55-60\% and 45-66\%, respectively (Gujar 1978). Eggs are placed on maturing pods in the field, where the infestation begins. Throughout the storage period, all threshed seeds are vulnerable to attack. Up on hatching, the grubs bore into the grains and devour the internal component, leaving the shell empty. Adults emerge from circular holes in the grains after pupation, causing not only quantitative but also qualitative losses such as nutritional loss, germination loss and rendering the grains unsuitable for human eating and seed production, as well as lowering their market value (Ali et al. 2004). Mookherjee et al. (1970) discovered that the pulse beetle infested leguminous seeds 32-64 per cent more than cucurbitaceous and solanaceous vegetable seeds, as well as oil seeds (3\%). After 6 months of traditional storage, 50 pulse beetles were discovered in stored pulse grains (Caswell, 1973). Infestation begins in the field and continues during storage. The months of July through October are when the most harm is done (Chakraborty \& Mondal 2015). Storage of food grains is an important part of food security.

According to the FAO report (2004), insect pests cause a major loss during storage of grains and other durable commodities such as pulses and oilseeds in developing countries. In India, farmers commonly store seed in gunny bags and keep them in wooden planks in the room for planting the next season, with little regard for insect pest assault during storage periods (Kumar et al. 2016). About 40 million tonnes of food grains are stored as a buffer stock in several warehouses and godowns in our country. The rate of ageing is slowed by low seed moisture content and storage temperature (Coolbear 1995). According to Roberts (1973), the viability of seeds in storage rises as seed storage moisture and temperature drop. In the tropics, poor storage conditions have been observed to cause a $10 \%$ decrease in seed quality 
(Genchev 1997). Among the pests, insect alone causes 10- 50\% damage (Anonymous 2012). Henceforth, there is a constant need to protect the stored products against deterioration, particularly loss of quality and quantity during storage. The present investigation was undertaken to assess the losses caused by pulse beetle during storage of chickpea grains in various storage structures.

\section{Materials and Methods}

The present investigation was carried out in Department of Entomology, CCS Haryana Agricultural University, Hisar, Haryana. Chickpea grain samples (500g each) were collected during August, September and October from different storage structures (metal bins, plastic bags, gunny bags, earthen pots and earthen pots + sand) in 15 villages of Rewari, Hisar and Mahendergarh district in the year 2017 and 2018. These samples were examined in laboratory to find out the moisture content of the grains, weight and number of damaged and healthy grains was recorded for each sample to detect infestation. The data was analyzed in terms of per cent infestation of bruchids, per cent moisture of seed and per cent use pattern of storage structures.

\section{Results and Discussion}

A total of 173 samples were collected in all three districts out of which 63 (36.42\%) samples were found infected with pulse beetle in 2017. In the same year chickpea samples from Rewari district were observed with higher infestation by pulse beetle followed by Hisar and Mahendergarh. In Mahendergarh maximum infestation was recorded in September i.e. 45 per cent followed by
October (35.00\%) and August (5.88\%) with moisture content of 10.90, 10.15 and 10.12 per cent, respectively. The data from Hisar samples revealed that maximum infestation of 65 per cent was observed in the month of September having the moisture content of 11.32 per cent. The infestation of pulse beetle was comparatively lower in the month of August (10.53\%) and October (40.00\%) having moisture content of 10.30 and 11.12 per cent, respectively. In Rewari the infestation was 55 per cent in October, 50 per cent in September and 11.76 per cent in August with moisture content of 11.28, 11.46 and 10.45 per cent, respectively (Fig 1). In 2018, a total of 177 samples were collected throughout the three districts, with 68 $(38.42 \%)$ of them showing signs of pulse beetle infestation. Chickpea samples from Rewari district had the highest pulse beetle infestation, followed by Hisar and Mahendergarh. In Mahendergarh, the highest infestation was 52.63 per cent, followed by 35.00 per cent in October and 10.00 per cent in August, with moisture content of 11.13, 10.88 , and 8.55 per cent, respectively. The maximum infection of 55 per cent was found in the month of September, with a moisture level of 11.08 percent, according to data from Hisar samples. Pulse beetle infestation was lower in August (15.00\%) and October $(44.44 \%)$, with moisture content of 8.98 and 11.14 per cent, respectively. In Rewari, the infestation was 60 per cent in September, 55 per cent in October, and 11.76 per cent in August, with moisture content levels of 11.06, 11.24, and 9.26 per cent, respectively (Fig 2). 


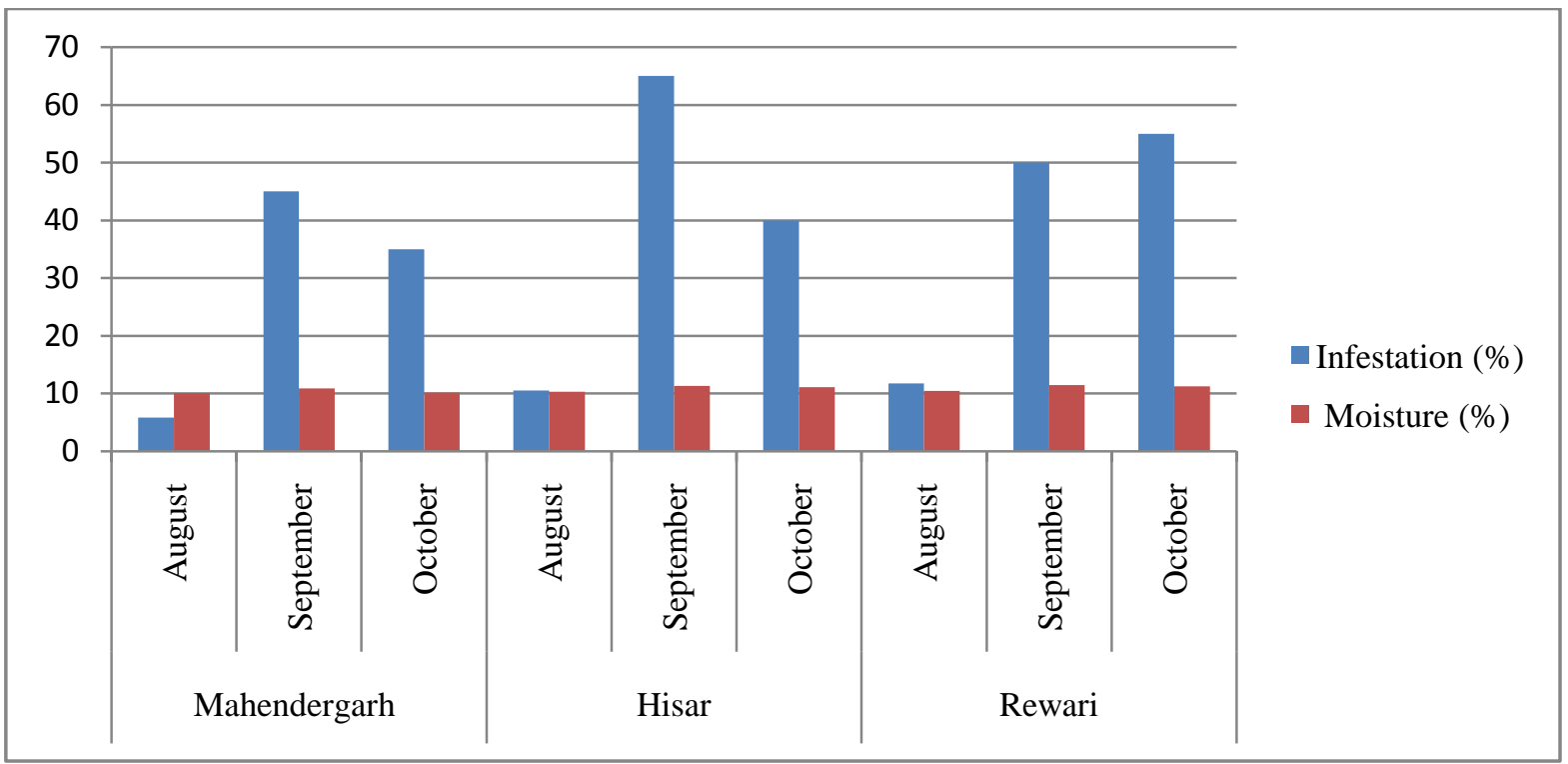

Fig 1. Pulse beetle infestation in chickpea grains in different district of Haryana during 2017

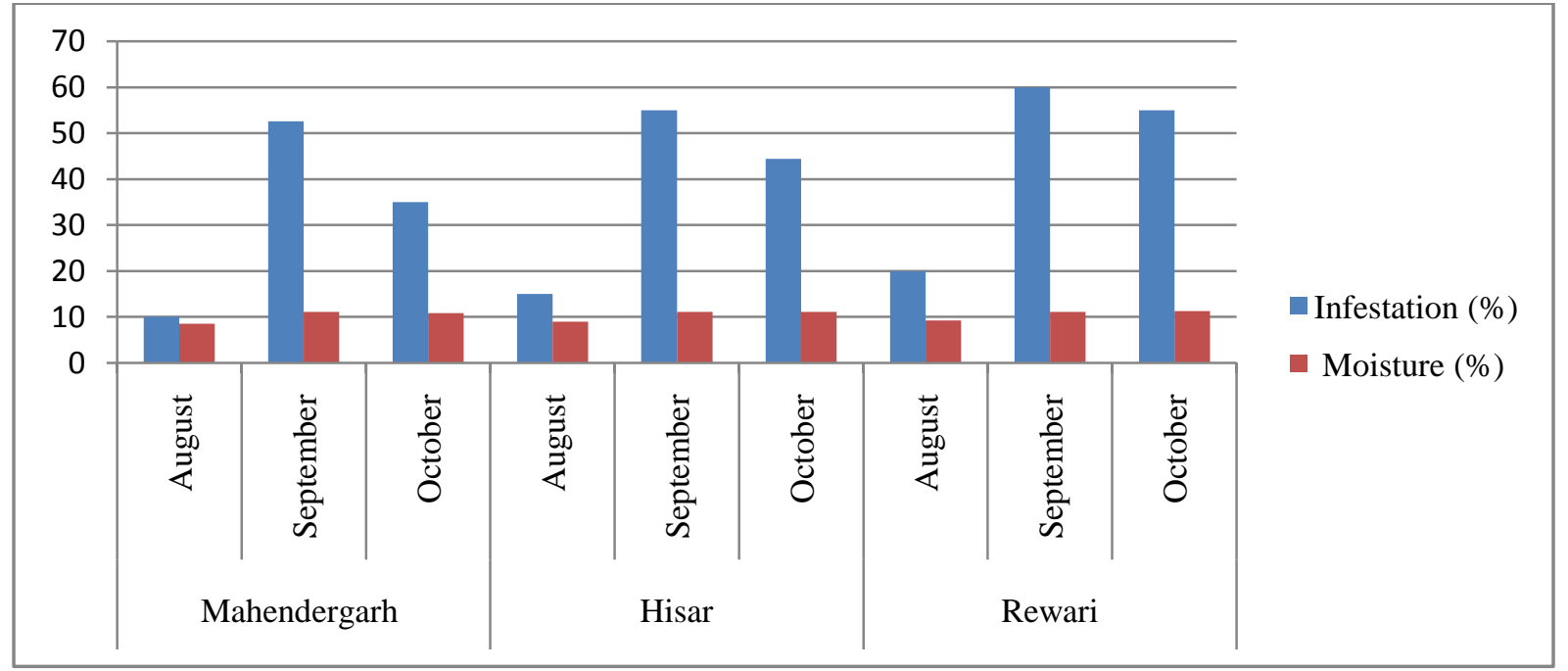

Fig 2. Pulse beetle infestation in chickpea grains in different district of Haryana during 2018

It is evident from Fig 1 and 2 that the infestation increases as the moisture of chickpea seeds increases where the peak infestation was recorded in September. In accordance to the present investigation, Sharma et al. (2013) concluded that major insect infesting chickpea was $C$. chinensis which reached its peak during SeptemberOctober $(38.05 \%)$ followed by 15.75 per cent during June-July and 11.23 per cent during January-February. They also stated that the samples with highest infestation of pulse beetle $(56.2 \%)$ were collected from Bhiwani and Hisar districts. The samples from Rewari and Mahendergarh were recorded with 50.7 per cent of pulse beetle infestation during September-October. According to Shaheen et al. (2006) different varieties of chickpea having moisture content of 9.04-11.33 per cent were reported with $28.36-54.46$ per cent damage by pulse beetle. Chakraborty \& Mondal (2016) revealed that the average 
damage recorded was highest on cow pea (34.95\%) followed by green gram $(32.73 \%)$, black gram $(30.76 \%)$, small pea $(1.45 \%)$ and kidney bean $(0.55 \%)$. According to Singh (2020) per cent damage was calculated which was recorded as grain content loss of 61.34 per cent in smaller variety and 61.59 per cent in larger variety of pigeopea. Deshpande et al. (2011) studied the varietal resistance and susceptibility in cowpea to bruchid Callasobruchus maculatus. They found that the infestation ranged from 42.71 to 97.29 per cent with a mean of 80.33 per cent. Also, moisture content was positively correlated with bruchid damage. Bajiya (2009) also found that the samples with moisture content up to 10.00 per cent were subjected to 67.34 per cent infestation with different insect pests. In the samples having moisture content between 10.10 to 13.50 per cent, 81.81 per cent were infested while the samples having moisture content more than 13.50 per cent, the infestation was 80.00 per cent.
Furthermore, in the present study, it was found that in 2017 maximum number of farmers $(51.45 \%)$ used metal bins followed by gunny bags $(31.79 \%)$, plastic bags $(16.76 \%)$, Earthen Pots $(6.51 \%)$ and Earthen Pots + sand $(2.35 \%)$ to store the chickpea grains. Among them 70.91 per cent gunny bag samples were found infested with pulse beetles followed by plastic bags (48.28\%), metal bins (11.24\%) and Earthen Pots (9.80\%). Interestingly, no infestation found in the samples stored in Earthen Pots + sand (Fig 3). The majority of farmers $(40.11 \%)$ stored chickpea grains in metal bins, followed by gunny bags $(31.64 \%)$, plastic bags (15.82\%), Earthen Pots (7.91\%) and Earthen Pots + sand (4.52\%) in 2018. Pulse beetles were identified in 53.62 per cent of gunny bag samples, followed by plastic bags $(20.29 \%)$, metal bins $(15.94 \%)$, and earthen pots $(10.15 \%)$. Infestation was not found in the samples kept in earthen pots with sand (Fig 3). Whereas, Ramasivan et al. (1968) said that no structure was free from pulse beetle damage.

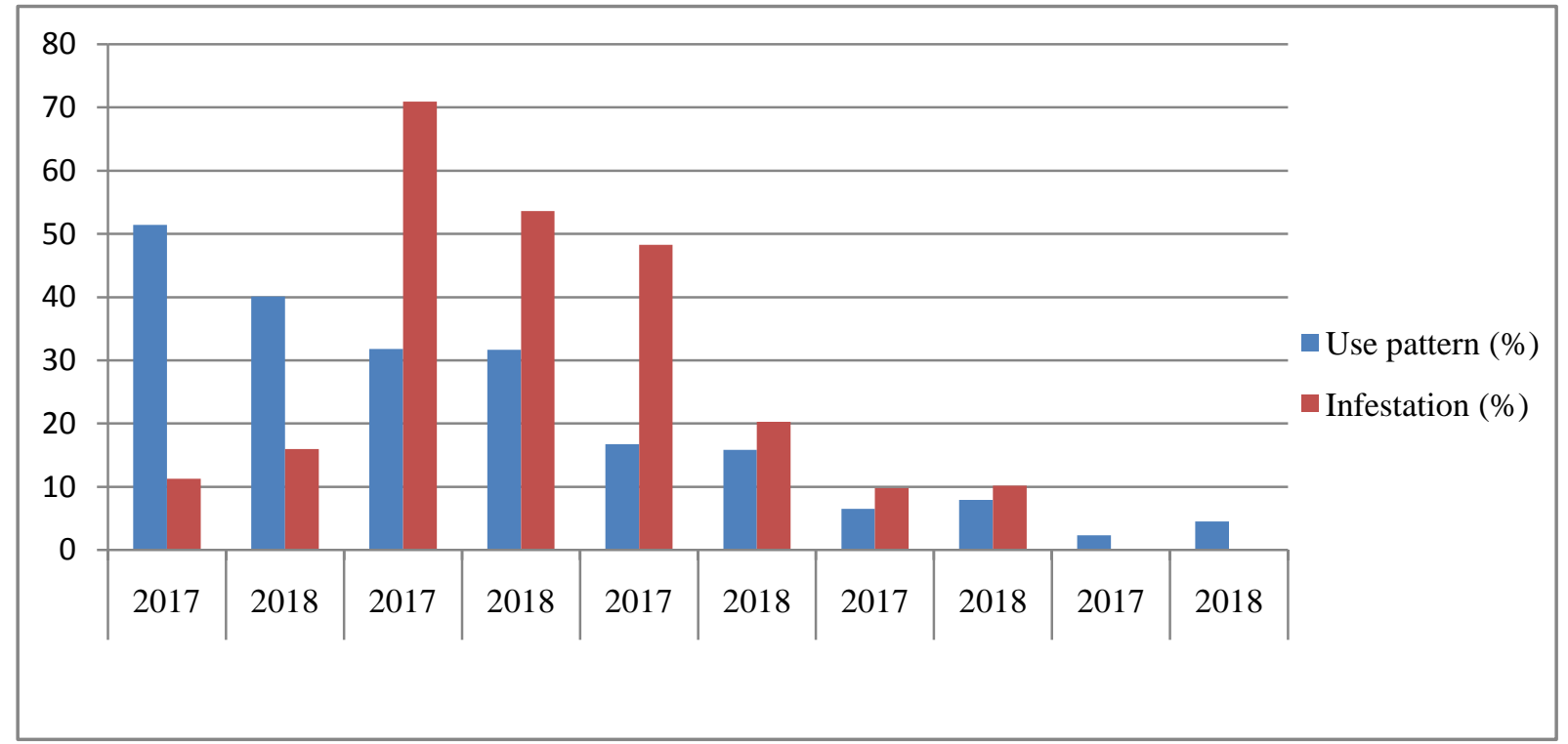

Fig 3. Storage structure use pattern and infestation of pulse beetle in chickpea 
Earthen jars were the most frequent form of storage in Gujarat, followed by jute bags, tin jars, wooden bins, piles, and pits (Patel 1970). Kharab (1981) examined the storage structures utilised by Haryana farmers for Bengal gram, finding that 36 per cent used bags and 64 per cent used bulk storage. In concurrence with the current investigation, Awaknavar et al. (1989) investigated five storage structures (i.e. metal bin, coal tar drum, gunny bag, plywood bin, and earthen pot storage) that could be employed on farms to protect pulses from the bruchid, $C$. chinensis. For metal bin, coal tar drum, gunny bag, plywood bin, and earthen pot storage, percentage weight losses were 3.2, 4.2, 4.8, 6.3, and 5.0, respectively. Similarly, Gupta (1990) evaluated the storage methods for pulses in Rajasthan, finding that 24 per cent of farmers adopted bags and 76 per cent used bulk storage. During the 2005-06 academic year, Bhargava \& Choudhary (2007) conducted a survey in all of Rajasthan's districts. They found that Callosobruchus spp. caused the most grain damage in loose storage and the least in metal containers. Accordingly, Bajiya (2009) recorded that the maximum infestation was in mud pot and bhukhari $(100 \%)$, followed by loose $(85.00 \%)$, bag $(74.46 \%)$, kothi $(66.66 \%)$, stone bin $(50.00 \%)$ and metal container $(38.88 \%)$. The storage practices and store receptacles/ structures commonly observed in Jaipur districts were bag $(37.60 \%)$, metal container $(14.40 \%)$, loose $(16.00 \%)$, kothi $(7.80 \%)$, stone bin $(8.00 \%)$, bhukhari $(8.00 \%)$, earthen pot $(6.40 \%)$ and pusa bin $(2.40 \%)$.

\section{Conclusion}

The data on both the year shows that maximum infestation of chickpea samples by pulse beetle was observed in Rewari district followed by Hisar and Mahendergarh. Highest infestation of pulse beetle was observed in the month of September followed by October. It was found that maximum number of farmers used metal bins followed by gunny bugs, plastic bags, Earthen pots and Earthen pots + sand to store the chickpea grains. Among different storage structures maximum infestation was observed in gunny bag samples followed by plastic bags, metal bins and earthen pots. There was no infestation of pulse beetle was observed in those samples which were stored in earthen pots along with sand.

\section{Acknowledgement}

The authors are thankful to Head of the Department, Department of Entomology, College of Agriculture, Chaudhary Charan Singh Haryana Agricultural University, Hisar, India, for providing facilities, input requirements and advice necessary for the experimentation.

\section{References}

Ali SM, Mahgoub SM, Hamed MS \& Gharib MSA. 2004. Infestation potential of Callosobruchus chinensis and C. macuatus on certain broadbean seed varieties. Egyptian Journal of Agricultural Research, 82(3): 1127.

Anonymous (2011). Agricultural Statistics at a Glance, 2010-2011. Directorate of Economics and Statistics, Ministry of Agriculture, Govt. of. India, New Delhi.

Anonymous. 2012. Food and Agricultural Organization. Rome, Italy. 
Anonymous. 2016. Pocket Book of Agricultural Statistics. New Delhi, Ministry of agriculture and farmers welfare, Department of Agriculture, Cooperation \& Farmers Welfare, Directorate of Economics \& Statistics, pp.154, India.

Anonymous.

2019. https://www.cabi.org/isc/datasheet/10986. Centre for Agriculture and Bioscience International.

Arora GL. 1977. Taxonomy of the Bruchidae (Coleoptera) of Northwest India. Part I. Adults. Oriental insects, 11(sup7): 1-132.

Aslam M. 2004. Pest status of stored chickpea beetle, Callosobruchus chinensis Linnaeus on chickpea. Journal of Entomology, 1(1): 28-33.

Awaknavar JS, Krishnamurthy KC, Babu CK \& Ramakumar MV. 1989. Different storage structures for safe storage of pulses. Mysore Journal of Agricultural Sciences, 23: 526- 532.

Bajiya RS. 2009. Bio-ecology and management of pulse beetle, Callosobruchus chinensis (Linn.) on mungbean, Vigna radiata (Linn.) Wilczek. Ph.D. thesis submitted to Swami Keshwanand Rajasthan Agricultural University, Rajasthan.

Bhargava MC \& Choudhary RK. 2007. Grain interaction in stored products with relation to storage structures /receptacles used in different parts of Rajasthan. National Seminar Organic Waste Utilization and Ecofrindly Technologies for Crop Protection (Hyderabad), 147-149.
Caswell GH. 1973. The storage of cowpea. Samaru Agricultural Newsletter, Nigeria. 15: 20-73.

Chakraborty S \& Mondal P. 2015. Studies on the biology of pulse beetle (Callosobruchus chinensis L.) infesting cowpea. International Journal of Current Research, 7(12): 23512-23515.

Chakraborty S \& Mondal P. 2016. Effect of ambient environmental conditions on the level of infestation by pulse beetle on different legumes. International Journal of Current Research, 8(7): 33841-33846.

Chaturvedi SK \& Ali M. 2000. Pulses: Poor man's meat needs fresh fillip. The Hindu, Survey of Indian Agriculture, 66.

Coolbear P. 1995. Mechanisms of seed deterioration. In: Basra, A.S. (Ed.), Seed quality. Basic mechanisms and agricultural implications. Food Product press, London, 223-277.

Deshpande VK, Makanur B, Deshpande SK, Adiger S \& Salimath PM. 2011. Quantitative and qualitative losses caused by Callosobruchus maculatus in cowpea during seed storage. Plant Archives, 11(2): 723-731.

Genchev D. 1997. The seed coat as factor for breaking of common bean seeds (Phaseolus vulgaris L.). Bean Improvement Cooperative (USA).

Gujar T. 1978. Feeding of Callosobruchus maculatus F. (Coleoptera: Bruchidae) reared on different foods and temperatures. Journal of Stored Products Research, 22: 71-75.

Gupta HC. 1990. Use of non-insecticidal approaches in the management of pulse beetle (Callosobruchus chinensis) in 
stored pulses. Ph.D. thesis submitted to Rajasthan University, Jaipur, India.

Kharab SS. 1981. Insect species associated with stored bengalgram (Cicer arietinum) and losses caused by Callosobruchus chinensis in rural areas of Haryana. Ph.D. thesis submitted to CCS Haryana Agricultural University, Hisar, Haryana.

Kumar M, Kumar A, Kumar A \& Kumari H. 2016. Evaluation of Farmers Saved Seed of Green Gram and Chickpea in Munger District of Bihar. International Journal of Bioresource and Stress Management, 7(4): 773-777.

Mookherjee PB, Jotwani MG, Yadav TD \& Sircar P. 1970. Studies on incidence and extent of damage due to insect pests in stored seeds-II. Leguminous and vegetable seeds. Indian Journal of Entomology, 32(4): 350-355.

Patel GA. 1970. Incidence and extent of infestation of insects on stored food grains. Technical Bulletin No. 1, Department of Agricultural Gujarat State, Ahmedabad.

Ramasivan T, Krishnamurthy K \& Pingale SV. 1968. Studies on preservation of food grains in rural storage. Part II. Storage of grains in villages near Hapur. Bulletin of Grain Technology, 6: 60-75.

Roberts EH. 1973. Predicting the storage life of seeds. Seed Science and Technology, 1: 499-514.
Shaheen FA, Khaliq A \& Aslam M. 2006. Resistance of chickpea (Cicer arietinum L.) cultivars against pulse beetle. Pakistan Journal of Botany, 38(4): 1237.

Sharma R, Devi R, Kumar Sharma R \& Singh M. 2013. Incidence and extent of damage due to insect pests of stored chickpea Cicer arietinum (L.) in Haryana State, India. Legume Research: An International Journal, 36(2): 142-146.

Sharma R, Devi R, Soni A, Sharma U, Yadav S, Sharma R \& Kumar A. 2016. Growth and developmental responses of Callosobruchus maculatus (F.) on various pulses. Legume Research-An International Journal, 39(5): 840-843.

Singh A. 2020. Damage and weight loss due to Callosobruchus chinensis infestation in arhar and their effect on germination during storage of most susceptible months. Bulletin of Pure \& Applied Sciences-Zoology, 39A (2): 495-502.

Southgate BJ. 1979. Biology of bruchidae. Annual Review of Entomology, 449 - 473.

Sujeetha AR, Girish AG, Sankarganesh E, Sridhar M, Ghosh SK, Hadapad AP \& Venugopalan VP. 2020. Effect of gamma radiation on pulse beetle, Callosobruchus chinensis (1.) (Coleoptera: Bruchidae) with different storage conditions. Journal of Experimental Zoology, India, 23 (1): 569574. 